\title{
Szentkirályi, Endre. 2019, Being Hungarian in Cleveland: Maintaining Language, Culture, and Traditions. Saint Helena, CA. 292 pp.
}

\author{
Reviewed by Mártha Pereszlényi-Pintér, John Carroll University
}

Endre Szentkirályi studied English and German at Cleveland State University, earned a Master's Degree in English at the University of Akron, and a Ph.D. in Literary and Cultural Studies from the University of Debrecen. His earlier works include Cold War to Warm Cooperation: The Military Service of Cleveland Hungarians 1950-2014 (English-Hungarian edition; Budapest: Zrínyi Kiadó, 2014) and the oral history project, Clevelandben Még Élnek Magyarok? - Visszaemlékezések Gyüjteménye ['Do Hungarians Still Live in Cleveland? - a Collection of Memories']. Born and raised in and near Cleveland, Ohio, Szentkirályi teaches English and German at the middle and high school levels in Bedford, Ohio. His new study examines the history and experience of "being Hungarian in Cleveland," using a variety of survey tools and methods, and drawing on his own forty-seven years as an active member of this community. He investigates the community's history and social structures via studying its language, literature, culture, and traditions.

The most recent survey of the Hungarian community of Cleveland was Julianna Puskás's "The Magyars of Cleveland, 1880-1930," published in 2002 in Identity, Conflict, and Cooperation: Central Europeans in Cleveland, 1850-1930 (eds. Hammack, Grabowski and Grabowski; Western Reserve Historical Society Press). Based on a variety of sources, including oral histories, surveys, and local publications, Szentkirályi's new work updates and expands Puskás's information with extensive details. His book consists of a Forward, a Preface, an Introduction, five chapters and a Conclusion, four appendices, a bibliography, endnotes, an index, and a few selected photos and illustrations. The information he provides on organizations and their past and present infrastructures is encyclopedic: it is a serious work geared toward a scholarly readership, suitable for researchers seeking systematic information as well as historical and archival sources. At the same time, it is no less accessible for the average reader interested in ethnic-community survival in general and in American-Hungarians in specific.

It is a common saying that Cleveland is home to the largest number of Hungarians outside of Budapest, albeit in truth Cleveland Hungarians live at least in the top ten areas of Hungarian population outside Hungary. Szentkirályi also cites other American cities in addition to Cleveland that have significant Hungarian populations: New Brunswick, NJ, Manhattan, Chicago, Los Angeles and San Francisco. There are also many smaller American towns with

*mpereszlenyi@jcu.edu

$($ (c) $)$ EY

ULIS D-Sorke 
Hungarian communities. These may be bound together by a church that is nowadays located in a crumbling neighborhood, but such places may just as well be lively locales of parties, picnics, and other communal events. Sometimes, language instructing still occurs in these places, organized by fiercely proud volunteers who devote their time, labor and money for the sake of preserving the community's Hungarian identity.

Szentkírályi is eminently qualified to author this work, as his own life reflects the values that Cleveland area Hungarians and their descendants hold. He describes how he has been an avid Hungarian scout leader for most of his life, on both the local and the international levels. He also worked, as an associate of the 56Films documentary film series directed by Réka Pigniczky, on several documentary films about the Hungarian diaspora, including Journey Home, Inkubator, and Heritage. He is a member of the American Hungarian Educators Association Board of Directors, the Cleveland Hungarian Heritage Society, and the American Hungarian Coalition based in Washington DC. Currently he is the President of the (Cleveland) United Hungarian Societies, an umbrella organization encompassing eight Hungarian churches and fourteen civic organizations in the Greater Cleveland area.

Szentkirályi lives with his wife Eszti Pigniczky in the Cleveland area. All four of their children speak fluent Hungarian, as well as participate in activities geared toward youth groups, such as the Hungarian Scouts and the associated Regös dance troupe. Szentkirályi emphasizes the importance of passing on cultural traditions including the Hungarian language in the family. On this subject, he repeatedly commends organizations such as the Hungarian Scouts, where young people can establish life-long friendships and participate in enjoyable undertakings designed to teach them about their cultural heritage while maintaining their language skills, because the Scouts' activities are all conducted in Hungarian.

Having fled their homeland in 1956, Endre Szentkirályi's own parents still maintained a close grip on their heritage, as did many parents of preceding and succeeding generations. Szentkirályi repeatedly affirms that cultural maintenance is rooted in the home and family. Parents such as his own have given their children a firm grounding in "Hungarianness." Older generations may have spoken only Hungarian at home, but dedicated parents today still teach their children the Hungarian language albeit with some difficulty when not both parents are Hungarian or of Hungarian origin. Children might attend Hungarian church, participate in Hungarian Scouts, and on Monday evenings attend Hungarian School. As a teenager, Szentkirályi himself joined the Regös Hungarian dance group where he met other Central and Eastern Europeans at dance festivals, and thus realized that he had much in common with American Ukrainians, Croats, Serbs, Polish, and other national-ethnic origin-groups maintaining their heritage in the United States. Szentkirályi notes that these people, the acquaintance with whom turned out to be a formative part of his own life, who have lived under oppression, appreciated freedom and opportunity more than most of his American-American friends. The literature that these former-European parents and community leaders had their children and youngsters read and the personal recollections they recounted to them were rife with stories of adversity and oppression: exile to Siberia, government collectivization of family businesses, incarceration for religious activities, and more. Thus, his heroes were not American baseball players or rock or movie stars, but rather Hungarians like Bishop Vilmos Apor, who helped save Jews during the war and then was killed protecting girls and women from the brutality of the Soviet soldiers, or Cardinal Joseph Mindszenty, who was jailed and tortured before 1956.

In Chapter One, "Background, the Evolution of Today's Cleveland," Szentkirályi delineates the six waves of immigration from Hungary to the U.S. or to Cleveland since the mid- 
1800s to the present, stressing the legacies of each wave: 1) Those who arrived in the mid-1800s but did not have much of an impact as a group with its unique cultural identity. 2) Óamerikás" ['old-timer American/s'], who arrived in the late nineteenth or early twentieth century, and who made a lasting impact by building physical and cultural landmarks such as churches and synagogues. 3) The DPs (Displaced Persons) arriving after World War II, who expressed an explicit zeal to continue their homeland cultural life and likely made the largest and most longlasting impact on Cleveland's Hungarian institutions. 4) The '56-ers, who initially may have rejuvenated Cleveland's Hungarians but many of whom later assimilated into American life or eased into current institutions. 5) The 1960s, 1970s, and 1980s dissidents or refugees of Hungarian Socialism/Communism. 6) The final wave is comprised of the so-called brain drain, meaning post-Socialist Hungarian professionals arriving in the late 1990s through the present day.

Still in the same Chapter One, Szentkirályi attempts to establish just how many people of Hungarian ancestry reside in the Cleveland area by means of surveys, such as Census Bureau data since 1940 through 2010. Data from the most recent American Community Survey, of 2015, show that the number of Hungarian speakers in Cuyahoga County is between 2,458 and 3,282. Numerous and meticulously researched charts and tables of statistical data figure prominently in Szentkirályi's investigations, but he notes that ancestry alone far from sustains an on-going Hungarian identity, which entails an entire spectrum from symbolic ethnicity (exemplified by declarations such as: "My grandmother was Hungarian, and I like goulash") to transnational immigrants who have just recently arrived from Hungary. Besides census and survey data, another ingenious way of shedding light on the Hungarian community in the Cleveland area is to examine the number of Hungarian families conducting Hungarian-language ceremonies in the funerals of their loved ones. Indeed, the result of this examination often shows just how much the Hungarian language was important to the deceased and by extension to his or her family. Another informal measuring method is consulting membership lists of Hungarian organizations and churches. It turns out that the largest list among these is that of the Hungarian Scouts, and while some lists overlap, people who are associated with Hungarian organizations are estimated to be around two to three thousand in 2017.

In Chapter Two, “Cleveland's Hungarian Traditions," Szentkirályi notes that the city's old Hungarian neighborhoods have in the last decades become a diminishing landscape. On the east side, in the Buckeye Road area, immigrants of the DP generation found themselves in a completely Hungarian world, where it was not uncommon for shops to display a sign saying: "English spoken here." The heyday of these almost entirely Hungarian neighborhoods was the 1920s, with the construction of ten churches, eight clubhouses for organizations, and countless businesses and offices. And this does not include the west side and the Lorain Avenue area, which in the decades following the 1920s, saw the building of four Hungarian churches. In the Buckeye area, two separate theatre groups operated, with plays and musicals, all in Hungarian, along with three movie theatres that showed Hungarian films. But by the late 1960s, fear of crime, changing populations, changing family values, and blockbusting by unscrupulous realestate agents drove people to the suburbs. Szentkirályi chronicles the once vibrant organizations that no longer exist and depicts the physical landscape of statues, gardens and memorials that are still there.

Chapter Three is titled "Culture," and in it Szentkirályi focuses on describing those Hungarian institutions, customs, and events that remain exceptionally vibrant today: the Scouts, the Hungarian Association, the Cleveland Hungarian Heritage Society and Museum, as well as 
many other organizations. Szentkirályi describes the Hungarian arts scene including music and Hungarian radio programs. He also mentions traditional Hungarian debutante balls as well as galvanizing events such as the closing and later reopening of St. Emeric Church, and major events such as Cardinal Mindszenty's 1974 visit, and the 1991 visit of Reverend László Tökés, the hero who sparked the 1989 Romanian Revolution leading to the demise of Ceaușescu. Neither does Szentkirályi neglect current politics as he investigates the trend of acquiring dual citizenship as well as national Hungarian-American voting tendencies in U.S. elections.

Chapter Four, "Language and Literature," is devoted to newspaper and book publishing and selling. Thousands of miles from Hungary, to make an effort to publish a book in the Hungarian language shows a sense of belonging and identity. Today, the Bocskai Radio Program (first begun in the 1980s as a student effort on the campus of John Carroll University), broadcasting on Sunday afternoons, has become the most significant news outlet, mostly replacing the role of print newspapers. Szenkirályi also discusses local authors such as István Eszterhás, father of Hollywood screenwriter Joe Eszterhás. The final pages of this chapter focus on Hungarian schools. Transforming the identities of children, teenagers, and adults from average monolingual Americans into bilingual, bicultural and transnational Hungarian Americans is a live example of de facto preservation of communal identity, as well as of the sense and concept of a spiritual homeland.

In Chapter Five, "Language Use Case Studies," Szentkirályi examines how it came to be that only five to seven percent of those living in the Cleveland area and report having Hungarian ancestry speak the language in their homes, yet they pass on this language and heritage. It turns out that their ways of preserving and maintaining their Hungarian identity include close-knit friendships among parents who value Hungarian education and ethnicity and who take an active part in the activities of their ethnic community. Eighteen young people living in the Cleveland area were chosen as case studies illustrating this reality, owing to their Hungarian-American background (Appendix Four consists of the full questionnaire the author used for his survey of this group of youngsters). Three major themes emerge from the examination of this case study: the influence of parents, the influence of peers as part of organized events, and the value of speaking the language as part of one's identity.

In the Conclusion to his book, Szentkirályi addresses recent developments, including the communication and outreach strategies of the community's core organizations, and he offers a hopeful outlook for its changing but enduring future. Today, Cleveland's Hungarian community has deep roots and Szentkirályi's research attests to the fact that it is still thriving. While this community is no longer defined by a physical neighborhood but rather by a set of cultural values, it remains vibrant and continues to value and preserve its heritage despite the ongoing impact of economic, social and cultural changes, or of demographic shifts and gentrification. Finally, Endre Szentkirályi maintains that although assimilation into American culture is an inevitable unstoppable process, it is still possible to continue the Hungarian language, culture, and traditions into the second and third generations and hopefully even further; but it takes perseverance and good old hard work. 